Kansas State University Libraries

New Prairie Press

\title{
EXPLORING FACTORS AFFECTING ATRAZINE CONCENTRATION IN THE BIG BLUE RIVER BASIN
}

Steven R. Kirby

Linda J. Young

Follow this and additional works at: https://newprairiepress.org/agstatconference

Part of the Agriculture Commons, and the Applied Statistics Commons

\section{(c) (1) $\Theta($}

This work is licensed under a Creative Commons Attribution-Noncommercial-No Derivative Works 4.0 License.

\section{Recommended Citation}

Kirby, Steven R. and Young, Linda J. (2000). "EXPLORING FACTORS AFFECTING ATRAZINE CONCENTRATION IN THE BIG BLUE RIVER BASIN," Conference on Applied Statistics in Agriculture. https://doi.org/10.4148/2475-7772.1239

This is brought to you for free and open access by the Conferences at New Prairie Press. It has been accepted for inclusion in Conference on Applied Statistics in Agriculture by an authorized administrator of New Prairie Press. For more information, please contact cads@k-state.edu. 


\title{
EXPLORING FACTORS AFFECTING ATRAZINE CONCENTRATION IN THE BIG BLUE RIVER BASIN
}

\author{
Steven R. Kirby and Linda J. Young \\ Department of Biometry \\ University of Nebraska-Lincoln
}

\begin{abstract}
Atrazine is a herbicide commonly used on corn and sorghum. Consumption of atrazine adversely affects humans. Environmental factors are related to atrazine concentration in the surface waters of the Big Blue River Basin using regression techniques. The usefulness of environmental factors as predictors of surface water atrazine contamination appears to depend on the time period.
\end{abstract}

\section{Introduction}

This work expands on that of McKenney, et al. (1997). In that study, the authors explored factors thought to be linked to the delivery of atrazine into the surface waters of the Big Blue River Basin including land use, land slope, and precipitation. The Big Blue River Basin is primarily located in southeast Nebraska, and continues into northeastern Kansas (Figure 1).

The conclusions in McKenney, et al. (1997) were broad and based on a visual inspection of coincidence maps generated in the Arc/INFO Geographic Information System (GIS). As noted by the authors, "... The southeastern portion of the basin [in Kansas] has a number of physical factors that would tend to increase atrazine losses through runoff . . . the northern portions of the basin [in Nebraska] are more intensely farmed to corn and sorghum, and thus more atrazine is applied." The goal of this work is to statistically relate atrazine concentration in the surface waters of the Big Blue River Basin to environmental factors.

\section{Surface Water Atrazine Documentation}

Atrazine is a water-soluble herbicide used to control broad-leaf weeds, primarily in areas planted with corn and sorghum. It is poisonous to humans and is likely to find its way into the water supply by leaching through soil or by run-off, with run-off being the most common transportation method. Removal of atrazine from water requires processes such as granular activated charcoal filtration in addition to conventional methods of water treatment (Adams, et al., 1990). Atrazine has an estimated half-life of 60 days in the top soil (Comfort et al., 1996), but its half-life is significantly longer in ground water and in subsurface soils (U.S. Environmental Protection Agency, 1988).

Atrazine can be applied as a preplant, a preemergence, or a postemergence treatment, or as a combination of these methods (Martin et al., 1997). In the Big Blue River Basin, 50\% of corn planting is complete in early May, while $50 \%$ of sorghum planting is complete in late May and early June (Nebraska Agricultural Statistics Service, 1992-1995; and Kansas Department of 
Agriculture, 1991, 1995, 1996). Thus atrazine would commonly be applied in the Big Blue River Basin from mid-April to June. Based on unpublished data from the Nebraska Cooperative Extension, McKenney et al. (1997) concluded that application rates in the Big Blue River Basin averaged 1.2 pounds of active ingredient per acre.

In the McKenney et al. (1997) study, several atrazine data sets were used. Here data from the National Water Quality Assessment (NAWQA) synoptic stations were considered. These data were collected at 34 sites throughout the Big Blue River Basin, on approximately the same dates and under similar flow conditions (Table 1). The same sampling methods were used at all sites and on all sampling dates. All sampling occurred in a single year; and the four sampling dates (July and November 1988, and March and May 1989) included portions of two different growing seasons. The locations of the sampling points are shown in Figure 2. The other atrazine data sets from McKenney et al. (1997) were not considered here because the sampling methods varied greatly.

The NAQWA readings were collected under low flow conditions. Under low flow conditions, shallow ground water contributes most of the water in unregulated streams (Stamer and Zelt, 1995). Thus detection of atrazine in surface waters at this time may be a consequence of atrazine in ground water. The data are not representative of high flow conditions that would lead to increased contamination due to run-off.

\section{Methods}

The data set used in the McKenney et al. (1997) study was reconstructed using both the report and Internet sources and entered into ArcView GIS. Additional spatial variables anticipated to be related to surface water atrazine levels were also included. Data were available on different sampling units. For example, atrazine is reported for a point, the corresponding NAWQA synoptic station. The acre percentages planted to corn and sorghum are on a county basis. Well depths are at points, but the points differ from those of the NAWQA stations. For each NAWQA station, the variables were spatially linked. This resulted in the observed value for each variable from the sampling unit in which the station lay being linked with the atrazine data collected at the station. Thus, the percentage of acres planted to corn for the county in which the station lies is reported for that station. In the case of well depth, the closest well to the station is linked to that station. Variables in the final data set included land slope in the map unit, percentage of corn to total planted acres in the county, percentage of sorghum to total planted acres in the county, well-depth, soil characteristics, sub-basin drainage area, and the depth to rock.

Crop acre percentages were derived from the 1992 Census of Agriculture (US Bureau of the Census, 1995). The percentages reflect the percentage of the county cropland planted in corn and sorghum. Slope data were collected from the State Soil Geographic (STATSGO) database, which is available from the Nebraska Resources Commission Internet site. Slope is in percentages. The slope is reported as the average of the maximum and minimum slope within the map unit spatially associated with each atrazine sampling point. Map units are polygonal areas representing the reporting units in the STATSGO database. They vary in size, with each unit 
representing a relatively homogeneous area. Soil hydrology score was also obtained from the STATSGO database. Originally soil hydrology was a categorical variable, with classes A, B, C, and $\mathrm{D}$. Those classes indicated the permeability of the soil in each map unit. Class A soils were very permeable, while class $\mathrm{D}$ soils had a slow infiltration rate. A weighted numerical average was generated from these categories as suggested by McKenney et al. (1997). Each category was assigned a number, and these values were weighted in each map unit according to the percentage of each soil component that was present in the map unit. The final scale based on the weighted averages consisted of numbers between 1 and 4, with 1 being very permeable and 4 having a very slow infiltration rate. Well depth data were collected from the Nebraska Resources Commission Internet site for registered ground water wells and from Kansas's WIZARD water well database. Well depth was measured in feet in both cases. Basic hydrology unit drainage area was measured in thousands of acres. These data were from the Nebraska Resources Commission Internet site containing basic hydrological unit boundaries by river basin. The basic hydrological units are the drainage areas of the smallest units in the Department of Natural Resource's system. They are not classic drainage areas as streams were used as dividing lines in some cases.

Spatial correlation among atrazine levels at the NAWQA sampling sites was investigated before analysis was conducted. Trends were removed from the data and semi-variograms were obtained for each of the four sampling dates using GEOEAS software. GEOEAS software is in the public domain and may be downloaded from www.epa.gov/ada/csmos/models/geoeas.html. These graphs indicate that spatial correlation was not present (Figures 3 and 4). Thus, multiple regression was used to explore the relationship between surface water atrazine level and environmental factors.

The atrazine point data along with the potential explanatory variables were exported to SAS. The data set was then analyzed for influential observations, primarily based on evaluation of the difference in fitted values resulting from deleting potentially influential observations. As a result of that analysis, six atrazine-level points were removed. The points that were removed are specified by their reference number and date from Table 1. Those points were the July 1988 point with reference number 35 , the November 1988 point with reference number 2, the March 1989 points with reference numbers 3 and 17, and the May 1989 points with reference numbers 2 and 20. Each of the outliers had much larger observed atrazine levels compared to the other points on the same sampling date. These large values could be due to point-source pollution, to an unusual combination of environmental factors and non-point-source pollution, or to measurement error. These observations were treated as missing data during subsequent analyses.

For each atrazine sampling date, stepwise regression with a maximum $\mathrm{R}^{2}$ criterion was used as an exploratory tool. After preliminary identification of important variables, a full hierarchical model was fit.

\section{Models}

What follows are the models generated for the four sampling dates. Application of the models to all areas along the Big and Little Blue Rivers produced negative predictions in some areas. The 
negative predicted values were set to zero. The response and explanatory variables considered are given below:

$\mathrm{Y}_{1}=$ Atrazine concentration July 1988,

$\mathrm{Y}_{2}=$ Atrazine concentration November 1988,

$\mathrm{Y}_{3}=$ Atrazine concentration March 1989,

$\mathrm{Y}_{4}=$ Atrazine concentration May 1989,

$\mathrm{c}=$ Percentage of acres of corn to total planted acres in the associated county,

$\mathrm{d}=$ Well depth, an approximate measure of how far down the aquifer is at various points,

$\mathrm{s}=$ The average percentage slope in the associated map unit,

$\mathrm{h}=$ Soil hydrology score, a measure of how quickly water infiltrates the soil, with higher numbers

meaning slower infiltration,

$\mathrm{a}=$ The number of acres (in thousands) in the basic hydrology unit, a measure of how much

drainage area is associated with the various points.

The regression model for July 1988 is

$\hat{y}_{1}=\max (4.19-23.08 \mathrm{c}-0.12 \mathrm{~s}-0.01 \mathrm{a}+0.82 \mathrm{~h}+1.96 \mathrm{cs}+0.14 \mathrm{ca}, 0)$.

The model has an $\mathrm{R}^{2}$ of 0.38 .

The regression model for November 1988 is

$\hat{y}_{2}=\max \left(-0.048-0.0019 d+0.13 \mathrm{~s}-0.03 \mathrm{~s}^{2}-0.00058 \mathrm{a}+0.000013 \mathrm{a}^{2}+0.0014 \mathrm{ds}, 0\right)$.

The model has an $\mathrm{R}^{2}$ of 0.23 .

The regression model for March 1989 is

$\hat{y}_{3}=\max \left(0.069-0.24 \mathrm{c}-11.68 \mathrm{c}^{2}-0.00040 \mathrm{~d}+0.091 \mathrm{~s}-0.011 \mathrm{~s}^{2}-0.00057 \mathrm{a}+0.016 \mathrm{~cd}+0.070 \mathrm{ca}, 0\right)$.

The model has an $\mathrm{R}^{2}$ of 0.74 .

The regression model for May 1989 is

$\hat{y}_{4}=\max \left(1.45+1.23 c-0.017 d+0.000088 d^{2}-0.0049 a-0.053 c d+0.20 c a, 0\right)$.

The model has an $\mathrm{R}^{2}$ of 0.61 .

The models have reasonable environmental interpretations. As corn percentage increases, so does the potential for atrazine use and atrazine contamination. Areas with a higher slope tend to be linked with more atrazine contamination due to run-off. Well depth was used as an indicator 
of how far down the aquifer is at various points. Surface water and sub-surface water interact. Areas where the aquifer is closer to the surface tend to be more easily contaminated by infiltration, and such contamination could affect surface water contamination levels. As the basic hydrology unit area increases the drainage area into the NAQWA site also increases, making it more likely that atrazine will get into the water. Soil hydrology score, a measure of how dense the soil is, can have an effect on atrazine levels, as denser soils tend to lead to more atrazine runoff, while more porous soils may lead to greater atrazine infiltration.

Although the models account for a significant proportion of variation, substantial variation is not explained. The most variation was explained by the March, 1989, model. In that case the residuals did not show any clear spatial trend. (Figure 5). Additionally, scatter-plots and correlation analysis revealed no association between the residual values and the values of the explanatory variables (corn, acres, well depth, hydrology group, and slope) for any of the models.

Percentage of corn planted acres was a significant explanatory variable in all but the November, 1988, model. This suggests that how much corn is planted during the season in the surrounding area has a significant effect on surface water atrazine levels. That the November model did not include corn may be due to the fact that the date is long after atrazine application, and atrazine has a half-life of roughly sixty days in top soil. However, its presence in the March model, a date even further from application, may imply that corn percentage is erroneously omitted from the November model. Well depth was a part of all the models except for July, 1988. This suggests that the interaction between atrazine contamination by infiltration and surface water atrazine contamination may deserve attention. Another consistently represented group of variables is that associated with atrazine contamination due to run-off. Slope, basic hydrological unit area, or both were represented in each of the models. As the atrazine data were collected under low flow conditions (which are less obviously linked to atrazine run-off), this fact could indicate that run-off contamination, perhaps from earlier rain events or snowmelt, may play a role in low flow conditions, or it could suggest the presence of unobserved factors. Additionally, the fact that all the models relied on different combinations of variables suggests that surface water atrazine level prediction is time dependent.

\section{Conclusion}

Environmental factors appear to play a role in atrazine contamination of the surface water of the Big Blue River Basin. This suggests that atrazine contamination is not simply a function of the amount of atrazine that is applied, although the prevalence of the corn percentage variable shows that it is important. Additionally, the results suggest that the environmental factors most closely related to atrazine contamination vary over time. Environmental factors appear to play a stronger role during certain time periods. That relationship is reflected in the higher percentage of variation explained during March and May. It may be the models are more successful during those times because weather conditions common in spring heighten the impact of environmental factors included in these models. Alternatively, the effect of atrazine from the preceding season should be least in March, and the atrazine levels observed in May may be primarily due to the recent applications. Because so many factors can affect atrazine levels and these vary greatly over space, prediction may be more difficult during time points further from application. Additionally, observations at a particular sampling point are impacted 
not only by the environment at that point but also by the environment at neighboring points, particularly those upstream. The models in this paper considered only the immediate environment of the sampling site. With further refinement, the role of environmental factors in atrazine contamination can be more precisely addressed, and the way that atrazine contaminates surface water can be better understood.

\section{Summary}

Atrazine is a herbicide commonly used on corn and sorghum. Consumption of atrazine adversely affects humans. Environmental factors are related to atrazine concentration in the surface waters of the Big Blue River Basin using regression techniques. The Big Blue River Basin is primarily located in southeast Nebraska, and continues into northeastern Kansas. Surface water atrazine data were from National Water Quality Assessment (NAWQA) synoptic stations. These data were collected at 34 sites throughout the Big Blue River Basin, on approximately the same four dates and under similar flow conditions. The environmental factors considered for inclusion in the models were percentage of acres of corn to total planted acres in the county, well depth, the average percentage slope in the STATSGO map unit, soil hydrology score, and the number of acres (in thousands) in the basic hydrology unit. The resulting regression equations were comprised of different groups of explanatory variables on the different sampling dates, and explained different amounts of variation in the atrazine data. The usefulness of environmental factors as predictors of surface water atrazine contamination appears to depend on the time period. The model $\mathrm{R}^{2}$ values ranged from 0.28 to 0.74 , indicating other factors not considered in this study have an impact on atrazine levels in surface waters of the Big Blue River Basin.

\section{Acknowledgments}

The authors thank Michael G. Dosskey for suggesting the problem and a reviewer for helpful suggestions. This research was supported in part by funding from the Rocky Mountain Research Station, the U.S. Forest Service, and the U.S. Department of Agriculture.

\section{References}

Adams, C.D., S.J. Radke, E.M. Thurman, R.A. Hulsey. 1990. Atrazine and its Degradation Products in Soil and Ground Water, and the Effectiveness of Water-Treatment Processes for their Removal. Proceedings from the $40^{\text {th }}$ Annual University of Kansas Environmental Engineering Conference. Lawrence, KS. (February 7).

Comfort, S.D., T.G. Franti, S.K. Smith. 1996. Pesticide Runoff and Water Quality in Nebraska. University of Nebraska Cooperative Extension EC 96-143.

Kansas Department of Agriculture. 1991, 1995, 1996. Crop Progress Calendar. Kansas Department of Agriculture, Division of Statistics, Topeka, KS. 
Martin, A.R., F.W. Roeth, R.G. Wilson, G.A. Wicks, R.N. Klein, D.J. Lyon. 1997. Guide for Herbicide Use in Nebraska. Nebraska Cooperative Extension, EC 97-130-D.

McKenney, M.S, T.G. Franti, K.D. Hoagland, M.G. Dosskey. 1997. Atrazine in Surface Waters of the Big Blue River Basin, Nebraska and Kansas. Private Paper generated at the University of NebraskaLincoln.

Nebraska Agricultural Statistics Service. 1992-1995. Nebraska Crops and Weather (published weekly). Nebraska Agricultural Statistics Service, Lincoln, NE.

Stamer, J.K. and R.B. Zelt. 1995. Herbicides and Insecticides. In J.O. Helgesen (ed.) Surface-WaterQuality Assessment of the Lower Kansas River Basin, Kansas and Nebraska: Results of Investigations, 1987-90. USGS Open-File Report 94-365.

United States Bureau of the Census. 1995. Census of Agriculture (1992). Geographic Area Series 1B [computer file]. US Department of Commerce, Bureau of the Census, Data User Services division, Washington, D.C. CD92-AG-1B.

United States Environmental Protection Agency. 1988. Atrazine-Health Advisory: Washington, D.C., Office of Drinking Water. 
Figure 1. The Big Blue River Basin

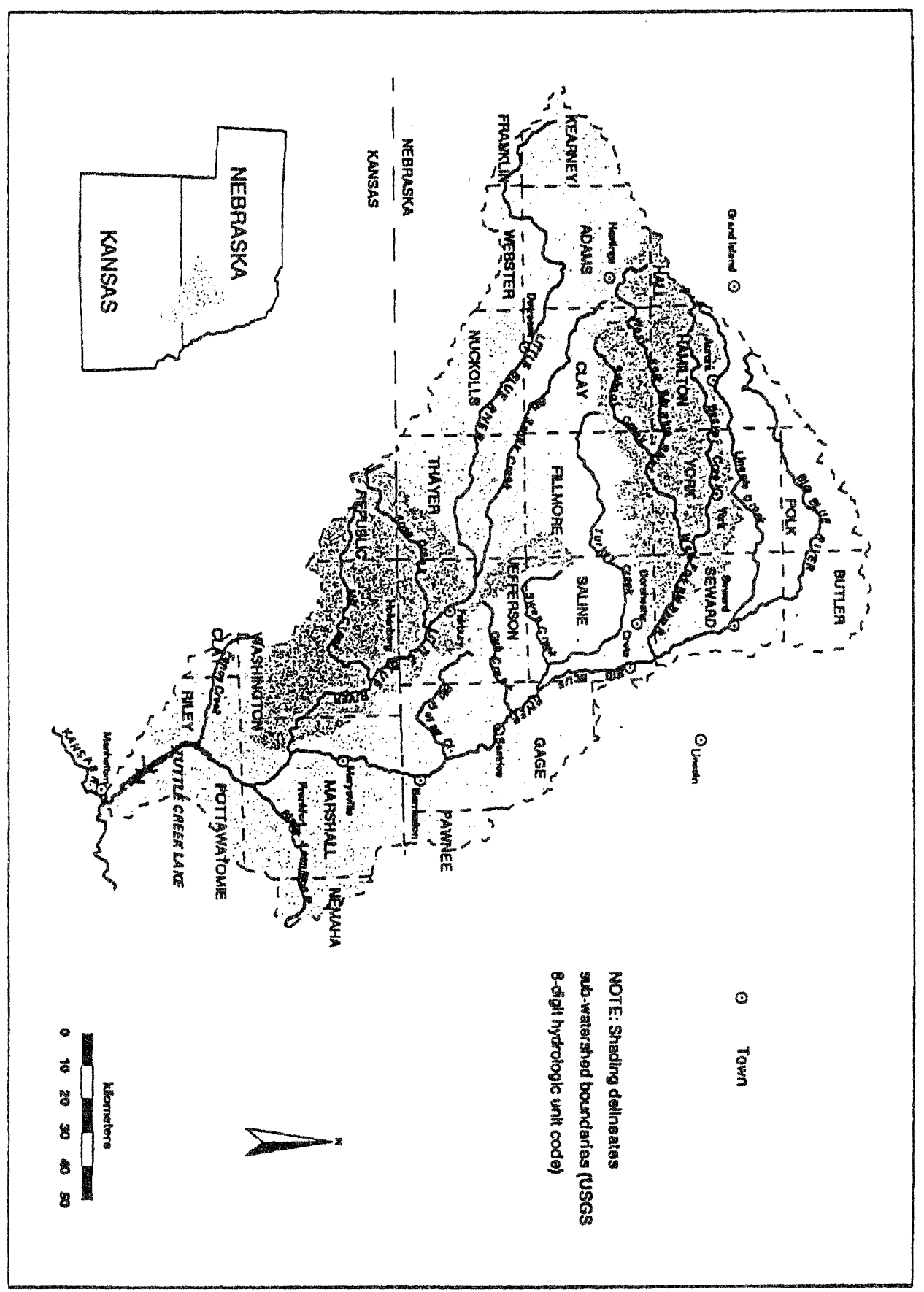


Table 1. Atrazine concentrations at NAWQA synoptic stations in the Big Blue River Basin. Atrazine levels are in units of micrograms per liter.

\begin{tabular}{|c|c|c|c|c|c|c|c|}
\hline Reference & Station Name & Latitude & Longitude & Jul-88 & Nov-88 & Mar-89 & May-89 \\
\hline 1 & Big Blue River at Surprise, NE & 41.0605 & 97.1835 & 2.4 & 0.3 & 0.6 & 0.4 \\
\hline 2 & Lincoln Creek near Aurora, NE & 40.5221 & 97.5821 & 8.8 & 11 & 2.6 & 32 \\
\hline 3 & Lincoln Creek near York, NE & 40.5438 & 97.3548 & 2.1 & 4.7 & 5.6 & 2 \\
\hline 4 & Lincoln Creek near Seward, NE & 40.5457 & 97.0843 & 2.5 & 0.1 & 0.7 & 0.1 \\
\hline 5 & Big Blue River at Seward, NE & 40.541 & 97.064 & 2 & 0.1 & 0.6 & NA \\
\hline 8 & W.F. Big Blue River near Hastings, NE & 40.3611 & 98.2006 & 0.4 & 0.1 & 0.3 & 1.6 \\
\hline 11 & W.F. Big Blue River near Stockham, NE & 40.4247 & 97.5806 & 1.5 & 0.1 & 0.5 & NA \\
\hline 17 & School Creek near Sutton, NE & 40.3749 & 97.5034 & 4.4 & 0.3 & 22 & 3.3 \\
\hline 20 & W.F. Big Blue River near McCool Junc., NE & 40.4327 & 97.3546 & 2.2 & 0.1 & 0.4 & 11 \\
\hline 27 & Beaver Creek near York, NE & 40.5029 & 97.3221 & 2.8 & 0.1 & 0.3 & 0.9 \\
\hline 32 & W.F. Big Blue River near Dorchester, NE & 40.4352 & 97.1038 & 3.6 & 0.2 & 0.3 & 1 \\
\hline 34 & Big Blue River near Crete, NE & 40.3547 & 96.5736 & 3.3 & 0.1 & 0.5 & 2.2 \\
\hline 35 & Turkey Creek near Geneva, NE & 40.3304 & 97.3114 & 12 & 3.5 & 1 & 3.8 \\
\hline 36 & Turkey Creek near Wilber, NE & 40.2848 & 97.0043 & 5.4 & 0.4 & 0.5 & 0.3 \\
\hline 37 & Swan Creek near Dewitt, NE & 40.2348 & 96.5911 & 1 & 0.1 & 0.3 & 0.3 \\
\hline 38 & Cub Creek near Beatrice, NE & 40.173 & 96.5002 & 9.8 & 0.3 & 0.3 & 0.2 \\
\hline 39 & Big Blue River at Beatrice, NE & 40.15 & 96.45 & 4.8 & 0.2 & 0.6 & 3.2 \\
\hline 40 & Big Indian Creek near Wymore, NE & 40.0632 & 96.4016 & 8.9 & 0.7 & 0.5 & NA \\
\hline 41 & Big Blue River at Barneston, NE & 40.0311 & 96.3516 & 4.3 & 0.2 & 0.4 & 1 \\
\hline 42 & Little Blue River near Hastings, NE & 40.2726 & 98.2405 & 4.9 & 0.3 & 0.2 & 0.1 \\
\hline 43 & Little Blue River near Deweese, NE & 40.1958 & 98.04 & 4.8 & 0.3 & 0.2 & 0.3 \\
\hline 44 & Little Blue River near Deshler, NE & 40.1243 & 97.4335 & 5.5 & 0.3 & 0.1 & 0.4 \\
\hline 45 & Little Blue River near Alexandria, NE & 40.1227 & 97.2326 & 4.9 & 0.4 & 0.2 & 0.5 \\
\hline 47 & Big Sandy Creek near Davenport, NE & 40.1826 & 97.4511 & 5.8 & NA & NA & NA \\
\hline 48 & Big Sandy Creek at Alexandria, NE' & 40.1406 & 97.232 & 3.3 & 0.1 & 0.1 & 0.1 \\
\hline 49 & Little Blue River near Fairbury, NE & 40.0654 & 97.1013 & 3.6 & 0.3 & 0.1 & 0.5 \\
\hline 50 & Rose Creek near Fairbury, NE & 40.0359 & 97.1014 & 7.2 & 0.1 & 0.1 & 0.3 \\
\hline 51 & Little Blue River at Hollenburg, KS & 39.980392 & 97.00431 & 4.1 & 0.2 & 0.1 & 0.8 \\
\hline 52 & Black Vermillion River near Frankfort, KS & 39.68417 & 96.437505 & 4.1 & 0.2 & 0.1 & 0.8 \\
\hline 55 & Big Blue River at Marysville, KS & 39.842227 & 96.660837 & 5.1 & 0.2 & 0.5 & 0.5 \\
\hline 56 & Little Blue River near Barnes, KS & 39.775837 & 96.858059 & 4.5 & 0.2 & 0.1 & 0.7 \\
\hline 57 & Fancy Creek at Winkler, KS & 39.472309 & 96.832198 & 2.8 & 0.4 & 0.1 & 0.5 \\
\hline 58 & Big Blue River near Manhattan, KS & 39.237226 & 96.5711989 & 2.8 & 3.1 & 1.4 & 1.3 \\
\hline 59 & Mill Creek near Hanover, KS & 39.9211116 & 96.937115 & 3.9 & 0.2 & 0.1 & 0.6 \\
\hline
\end{tabular}


Figure 2. Spatial Location of NAWQA Synoptic Stations

\section{Spatial Location of \\ Atrazine Sampling \\ Points}

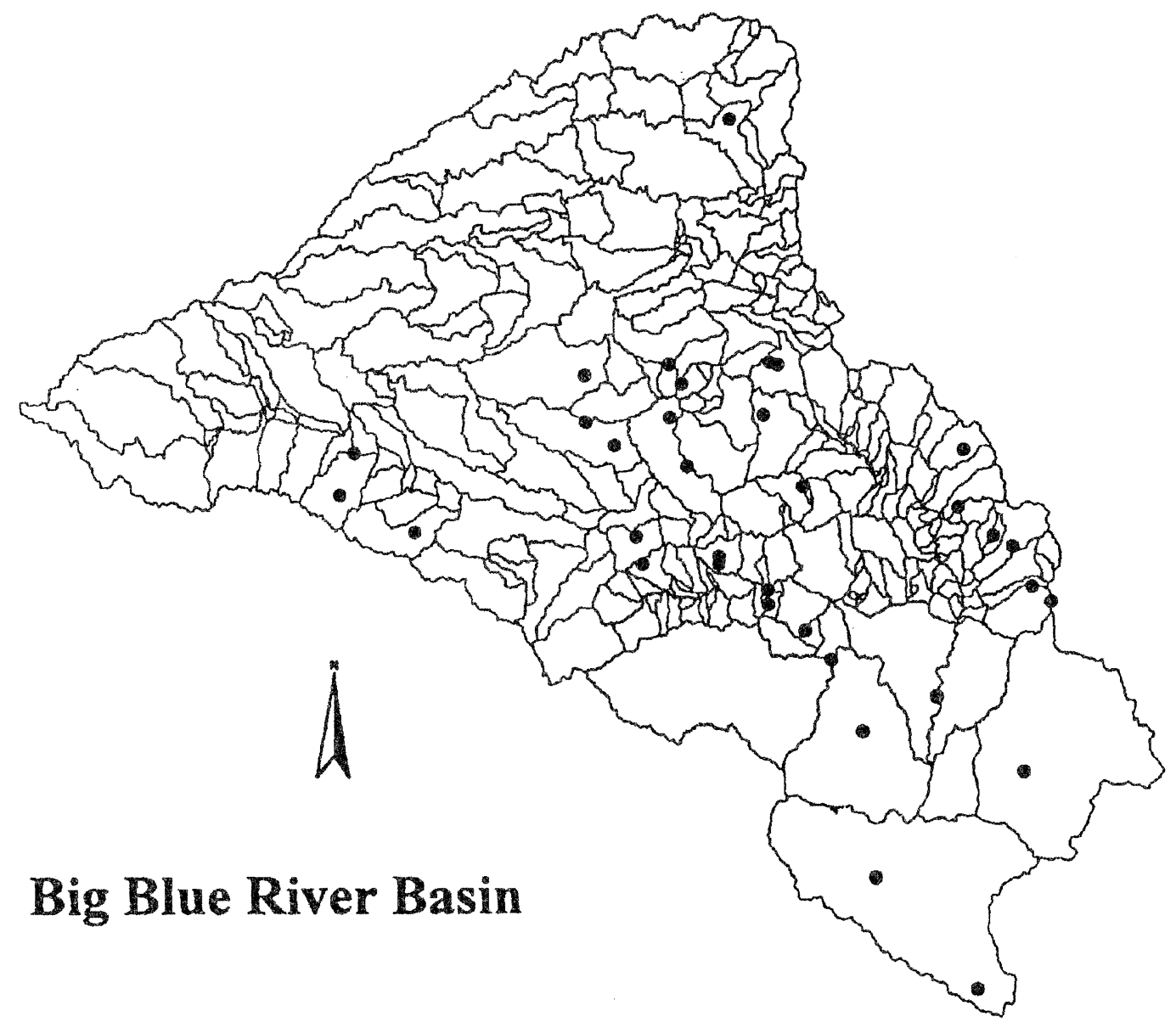


Figure 3. Semi-Variograms for July 1988, and November
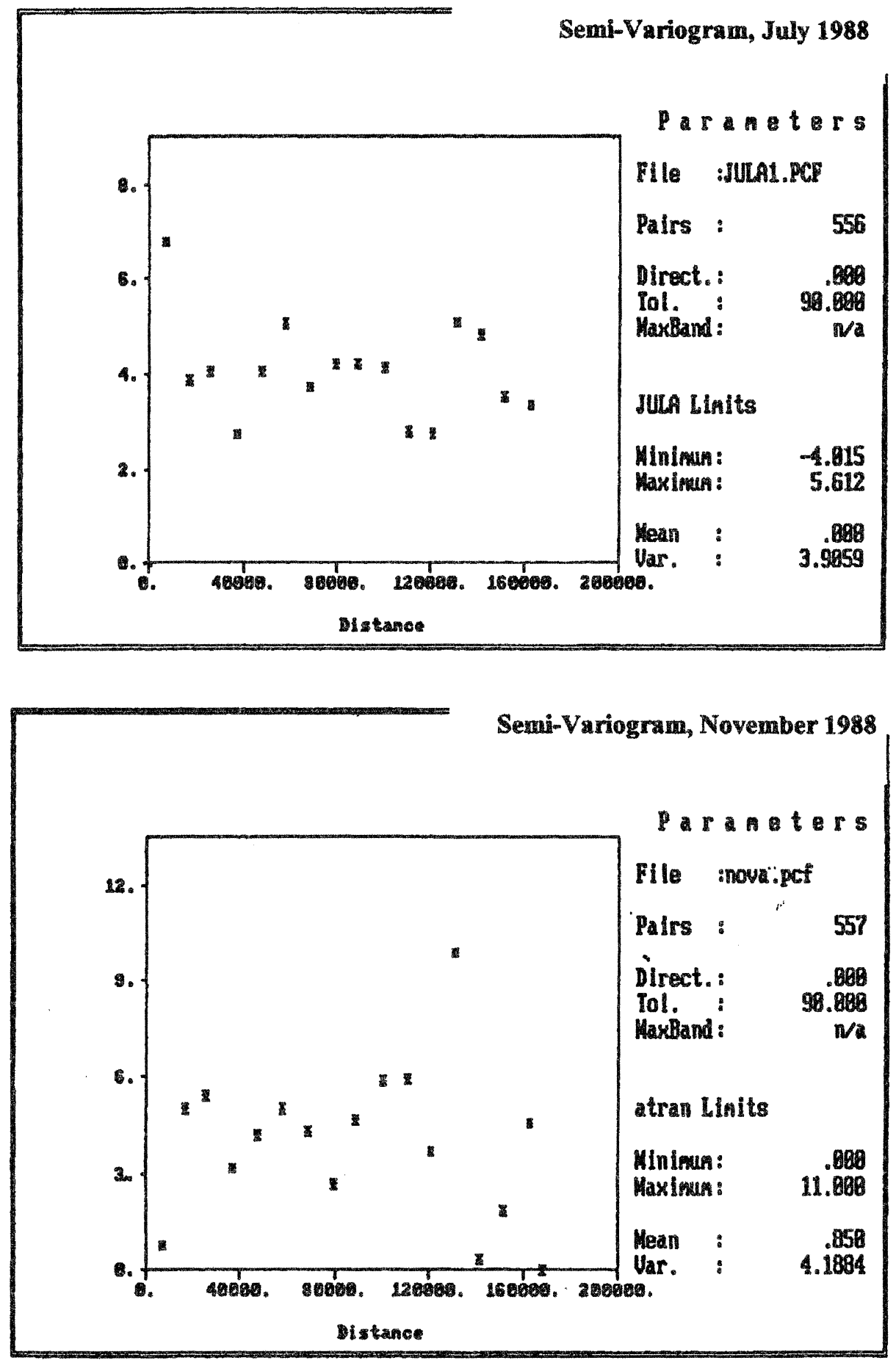
Figure 4. Semi-Variograms for March 1989, and May 1989
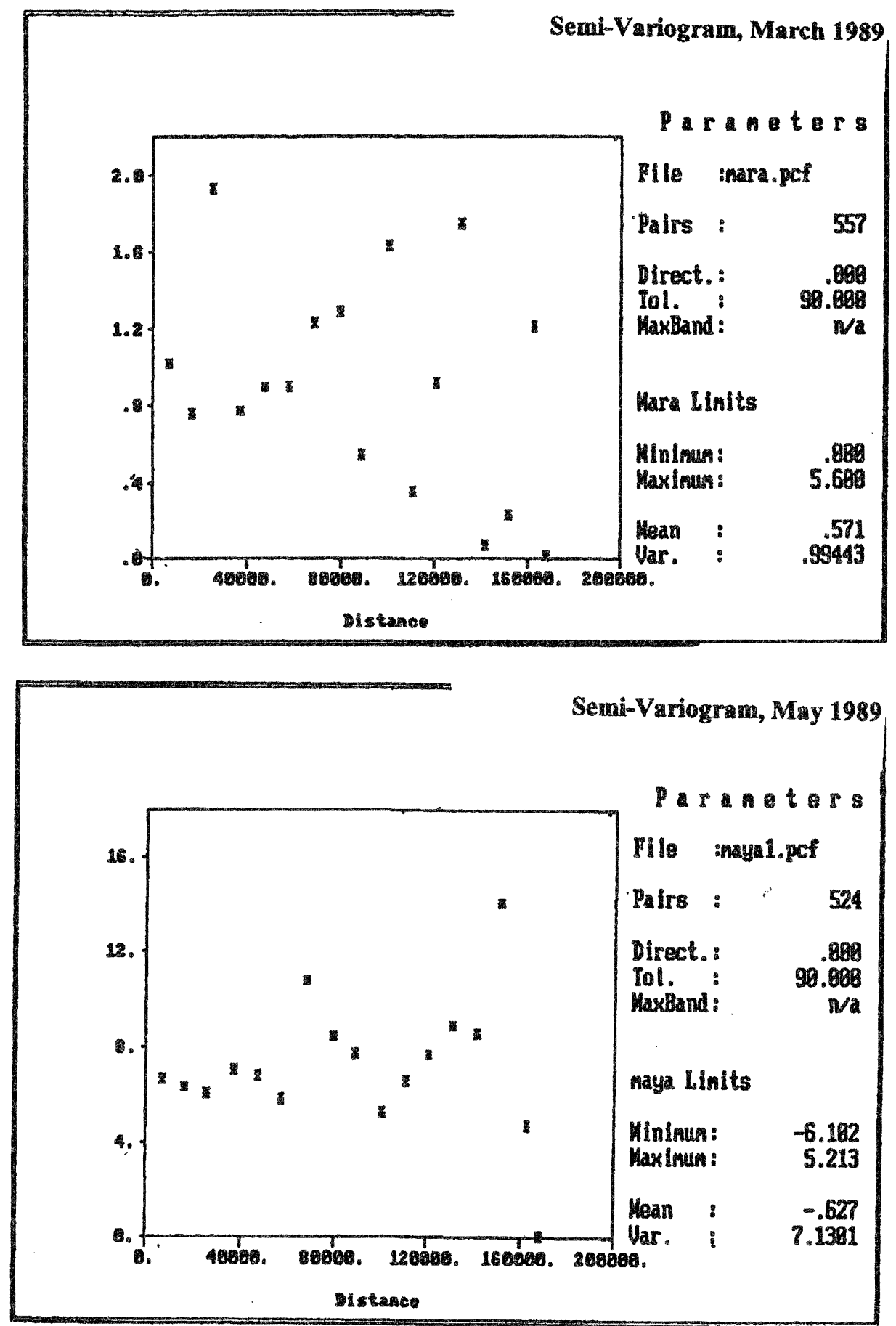
Figure 5. Spatial Location of March Residuals

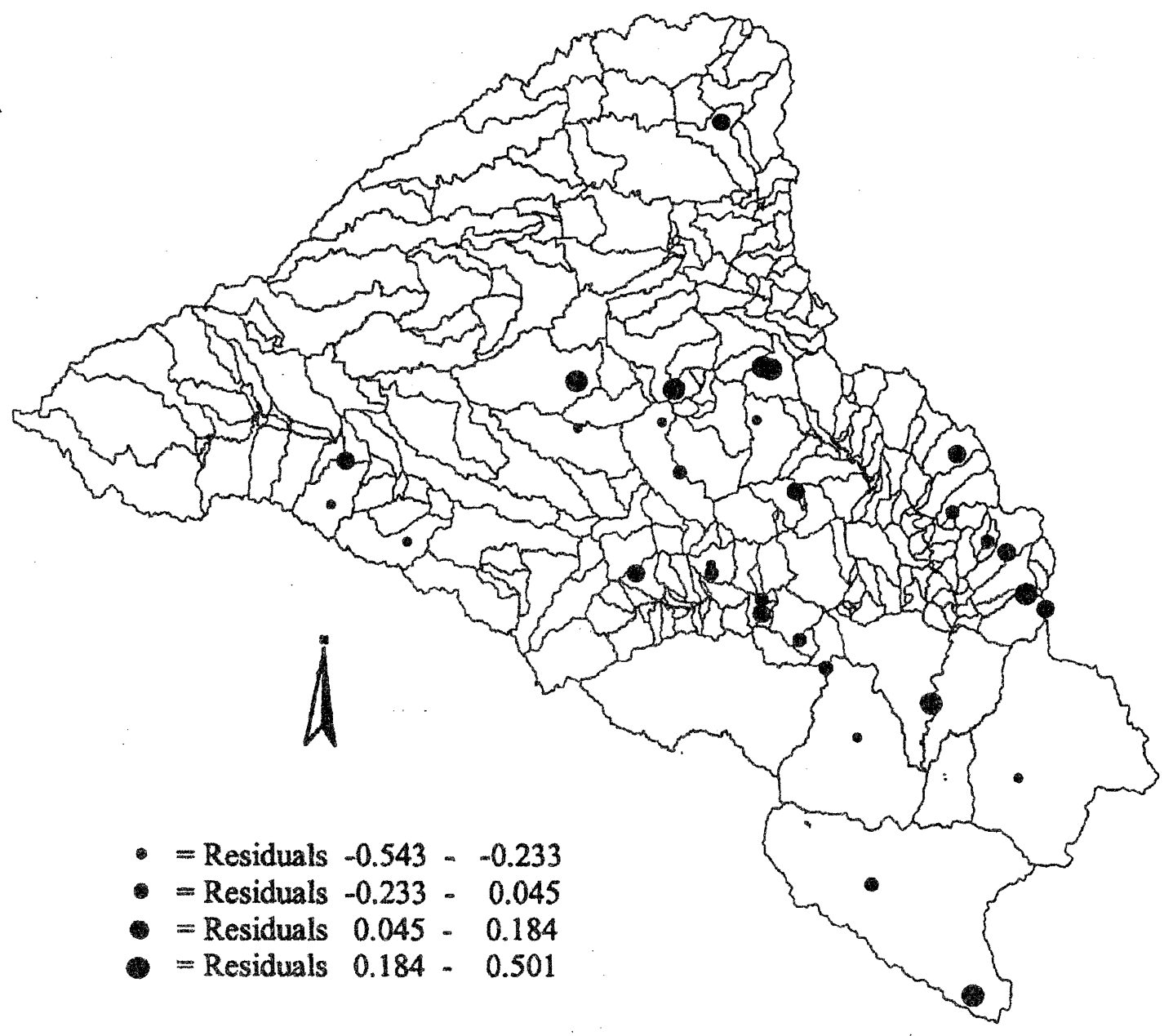

